\title{
Reply to Dr. Brown and Dr. Meyer
}

Citation for published version (APA):

Selten, J-P.., \& Termorshuizen, F. (2017). Reply to Dr. Brown and Dr. Meyer. Schizophrenia Research, 190, 184-184. https://doi.org/10.1016/j.schres.2017.03.021

Document status and date:

Published: 01/12/2017

DOI:

10.1016/j.schres.2017.03.021

Document Version:

Publisher's PDF, also known as Version of record

Document license:

Taverne

Please check the document version of this publication:

- A submitted manuscript is the version of the article upon submission and before peer-review. There can be important differences between the submitted version and the official published version of record.

People interested in the research are advised to contact the author for the final version of the publication, or visit the DOI to the publisher's website.

- The final author version and the galley proof are versions of the publication after peer review.

- The final published version features the final layout of the paper including the volume, issue and page numbers.

Link to publication

\footnotetext{
General rights rights.

- You may freely distribute the URL identifying the publication in the public portal. please follow below link for the End User Agreement:

www.umlib.nl/taverne-license

Take down policy

If you believe that this document breaches copyright please contact us at:

repository@maastrichtuniversity.nl

providing details and we will investigate your claim.
}

Copyright and moral rights for the publications made accessible in the public portal are retained by the authors and/or other copyright owners and it is a condition of accessing publications that users recognise and abide by the legal requirements associated with these

- Users may download and print one copy of any publication from the public portal for the purpose of private study or research.

- You may not further distribute the material or use it for any profit-making activity or commercial gain

If the publication is distributed under the terms of Article $25 \mathrm{fa}$ of the Dutch Copyright Act, indicated by the "Taverne" license above, 


\section{Letter to the Editor}

\section{Reply to Dr. Brown and Dr. Meyer}

With interest we read the comments by Drs. Brown and Meyer (Selten and Termorshuizen, 2017). We will not respond to all of the points they made, because the readers of Schizophrenia Research are competent enough to assess the evidence. They will certainly not need a power calculation to understand that the influenza hypothesis is not compatible with the observation that a pandemic with infection rates of $40-50 \%$ does not produce an even slightly increased risk. We gently remind Dr. Brown that he was a co-author of a paper that examined the effect of second-trimester exposure to the 1957 pandemic on the non-affective psychosis risk for Dutch citizens (Selten et al., 1999). The power of this study was large. Even if one assumes that the Relative Risk (RR) of non-affective psychosis for those exposed is only 1.3, the power to detect a significantly increased risk was $0.97(\alpha=0.05$; one-tailed testing). It is self-evident that such data-sets would yield significant results for first-trimester exposure, given a high RR.

It is true, Brown et al. (2004) conducted a validity study to assess the validity of particular antibody titres to demonstrate a recent infection, but the number of cases was small $(\mathrm{N}=51)$. The positive predictive value derived from this validity study (78\%, not $100 \%$ ) supports the idea that the serological studies by Brown et al. and Canetta et al. may have included some cases with non-recent infections. A neutral source states that the antibody titre should be 1:40, not 1:20 (Dowse et al., 2011).

The literature on maternal influenza and psychosis in offspring is a fine illustration of the points made by Ioannidis in his famous paper "Why most published research findings are false" (Ioannidis, 2005). The flexibility in designs, definitions, outcomes and analytical modes is almost infinite. Without any good reason the timing of exposure is claimed to be in the second trimester, the first trimester, the fourth or sixth month of gestation, or, with reference to bipolar disorder, the whole nine-month period. Such a flexibility greatly increases the risk of false-positive results.

The serological investigation (Canetta et al., 2014) that reported an association between maternal influenza and bipolar disorder with psychotic features in offspring was supported by a study that examined the prevalence of a clinical diagnosis of influenza among mothers of the same cohort (Parboosing et al., 2013). However, we wonder whether Brown and colleagues also examined the prevalence of a clinical diagnosis of influenza among mothers of cases of schizophrenia. If they performed such a study, a publication of the pertinent results would be helpful.

\section{Conflict of interest}

The authors declare no conflict of interest.

\section{Acknowledgment}

No acknowledgment.

\section{References}

Brown, A.S., Begg, M.D., Gravenstein, S., Schaefer, C.A., Wyatt, R.J., Bresnahan, M., et al., 2004. Serologic evidence of prenatal influenza in the etiology of influenza. Arch. Gen. Psychiatry 54, 322-328.

Canetta, S.E., Bao, Y., Dawn, M., Ennis, F.A., Cruz, J., Terajima, M., et al., 2014. Serologica documentation of maternal influenza exposure and bipolar disorder in adult offspring. Am. J. Psychiatry 171, 557-563.

Dowse, G.K., Smith, D.W., Kelly, H., Barr, I., Laurie, K.L., Jones, A.R., et al., 2011. Incidence of pandemic (H1N1) (2009) influenza infection in children and pregnant women during the 2009 influenza season in Western Australia - a seroprevalence study. Med. J. Aust. 194, 68-72.

Ioannidis, J.P., 2005. Why most published research findings are false. PLoS Med. 2 (8), e124 (Aug).

Parboosing, R., Bao, Y., Shen, L., Schaefer, C.A., Brown, A.S., 2013. Gestational influenza and bipolar disorder in offspring. JAMA Psychiat. 70, 677-685.

Selten, J.P., Termorshuizen, F., 2017. The serological evidence for maternal influenza as risk factor for psychosis in offspring is insufficient: critical review and meta-analysis. Schizophr. Res. (in press).

Selten, J.P., Brown, A.S., Moons, K.G., Slaets, J.P., Susser, E.S., Kahn, R.S., 1999. Prenatal exposure to the 1957 influenza pandemic and non-affective psychosis in the Netherlands. Schizophr. Res. 38, 85-91.

Jean-Paul Selten*

Fabian Termorshuizen

University of Maastricht, Psychiatry, Universiteitssingel 50, 4300 CC Maastricht, The Netherlands *Corresponding author. E-mail address: j.selten@rivierduinen.nl (J.-P. Selten).

26 February 2017 